\title{
DISSOLVED INORGANIC NUTRIENTS AND CHLOROPHYLL ON THE NARROW CONTINENTAL SHELF OF EASTERN BRAZIL
}

\author{
Gilmara Fernandes Eçal, Joselene Badú de Brito Santos Lopes ${ }^{l}$, \\ Marcelo Friederichs Landim de Souza ${ }^{2 *}$ and André Luiz Belém ${ }^{3}$
}

${ }^{1}$ Universidade Estadual de Santa Cruz, Programa de Pós Graduação em Sistemas Aquáticos Tropicais (Rodovia Ilhéus-Itabuna, km 16, 45650-000 Ilhéus, BA, Brasil)

${ }^{2}$ Universidade Estadual de Santa Cruz, Laboratório de Oceanografia Química (Rodovia Ilhéus-Itabuna, km 16, 45650-000 Ilhéus, BA, Brasil)

${ }^{3}$ Universidade Federal Fluminense

(Rua Miguel de Frias, 9, 24220-900 Niterói, RJ, Brasil)

*Corresponding author: marland@bgqmar.net

http://dx.doi.org/10.1590/S1679-87592014051306201

\section{A B S T R A C T}

The eastern Brazilian continental shelf is narrow and subject to the influence of a western boundary current system, presenting lower biological productivity than other regions. In this study, the distribution of water masses, dissolved inorganic nutrients, chlorophyll- $a$ and total suspended solids (TSS) on the inner shelf (< $35 \mathrm{~m}$ depth), between Itacaré and Canavieiras, eastern Brazil, is presented. Sampling surveys were carried out in March and August 2006 and March 2007. Tropical water (TW) prevailed during March 2006 and August 2007 with the lower salinity waters $(<36)$ found in most samples taken in March 2007, reflecting the influence of continental outflow and rain in coastal waters. Low concentrations of dissolved inorganic nutrients and Chl-a found were typical of TW and results suggested that the inner shelf waters were depleted in dissolved inorganic nitrogen in August 2006 and March 2007, and in phosphate in March 2006, potentially affecting phytoplankton growth. Stratification of the water column was observed due to differences in dissolved nutrient concentrations, chlorophyll- $a$ and TSS when comparing surface and bottom samples, possibly the result of a colder water intrusion and mixing on the bottom shelf and a deep chlorophyll maximum and/or sediment resuspension effect. Despite this stratification, oceanographic processes such as lateral mixing driven by the Brazil Current as well as a northward alongshore drift driven by winds and tides transporting Coastal Water can lead to an enhanced mixing of these waters promoting some heterogeneity in this oligotrophic environment.

\section{RESUMO}

A plataforma Leste do Brasil é estreita e sofre influência de um sistema de correntes de borda oeste, apresentando baixa produtividade biológica em comparação com outras regiões. Neste estudo, a distribuição de massas de água, nutrientes inorgânicos dissolvidos, clorofila-a e sólidos suspensos totais (SST) na plataforma interna ( $<35 \mathrm{~m}$ de profundidade), entre Itacaré e Canavieiras, leste do Brasil, são apresentadas. Amostragens foram realizadas no período de março e agosto de 2006 e março de 2007. A Água Tropical (AT) prevaleceu durante março de 2006 e agosto de 2007, mas com águas de salinidade mais baixa $(<36)$ encontradas na maioria das amostras obtidas em março de 2007, refletindo a influência da drenagem continental e chuvas em águas costeiras. As baixas concentrações de nutrientes inorgânicos dissolvidos e clorofila-a encontradas são típicas da AT e os resultados sugerem ainda que as águas da plataforma interna apresentaram nitrogênio inorgânico dissolvido como limitante em agosto de 2006 e março de 2007, e o fosfato em 2006, potencialmente afetando o crescimento do fitoplâncton. A estratificação da coluna d'água foi observada com base nas diferenças nas concentrações de nutrientes dissolvidos, clorofila-a e TSS quando se comparam as amostras de superfície e de fundo, possivelmente devido à intrusão de água fria e mistura na plataforma inferior e uma profundidade do máximo de clorofila e /ou efeitos de ressuspensão dos sedimentos. Apesar desta estratificação, processos oceanográficos como mistura lateral impulsionado pela corrente do Brasil, bem como um desvio em direção ao norte ao longo da costa impulsionado por ventos e marés que transportam água costeira, podem ocasionar maior mistura dessas águas e promover heterogeneidade nesse ambiente oligotrófico.

Descriptors: Coastal Water, Tropical Water, Brazil Current, Oligotrophic System, Phytoplankton, Redfield Ratio.

Descritores: Água Costeira, Água Tropical, Corrente do Brasil, Sistema Oligotrófico, Fitoplâncton, Razão de Redfield. 


\section{INTRODUCTION}

Dissolved inorganic nutrients $(\mathrm{N}, \mathrm{P}$ and $\mathrm{Si})$ that sustain primary production in marine environments can be of allochthonous (atmospheric deposition, groundwater seepage, fluvial and open ocean inputs) and autochthonous origin (benthic and pelagic remineralization). The relative abundance of these elements in the water can be evaluated by the well known Redfield molar ratio. Deviations from the optimal proportion for phytoplankton growth (Redfield's ratio of $16 \mathrm{~N}: 16 \mathrm{Si}: 1 \mathrm{P}$ ) caused by internal biogeochemical processes, allochthonous inputs and some oceanographic processes (such as upwelling, small eddies, or internal wave mixing) can be crucial to pelagic biological production (ADMIRAAL et al., 1990; TURNER; RABALAIS, 1994).

Specially on narrow continental shelves of western boundary current systems, which are characteristically oligotrophic, the spatial distribution of dissolved inorganic nutrients and phytoplanktonic biomass along the water column can be controlled by vertical and horizontal mixing (SÁNCHEZARCILLA; SIMPSON, 2002), caused by tides, internal waves, and wind action on the water surface. The synergetic action of these processes can result in the increment of dissolved nutrients and bottom particulate material and contribute to enhance primary production (MANN; LAZIER, 1996).

The most productive areas of the Brazilian continental shelf are located in its southern and southeastern sectors, where seasonal upwelling induces fertilization of the shelf waters, and where large rivers flow into the sea. On the northern Brazilian shelf, the contribution of the Amazon River has a major impact on primary production. The eastern and northern sectors of the shelf are, however, considered less productive (JENNERJAHN et al, 2010). The eastern Brazilian shelf is a typical tropical marine system (BERGER et al., 1996) and exhibits low primary and fish production; the phytoplaktonic biomass is dominated by pico and nanoplankton, and microbial processes prevail (EKAU; KNOPPERS, 1999). However, knowledge of the region is based on a few studies focused on the shelf and the open ocean. The very few studies geographically limited to small bays and estuaries (LEIPE et al., 1999) have suggested that the influence of fluvial inputs of material is confined to a narrow strip of the inner shelf. Organic matter and metabolic activity in eastern Brazilian coastal waters are also influenced by small mangrove-lined estuaries (OVALLE et al., 1999), but this region is characterized by an efficient dilution of continental inputs by the oligotrophic water of the Brazil Current (BC), as well as coming under the influence of oceanographic processes controlled by geomorphological constraints (MARONE et al., 2010).

In order to study such an important and complex environment, the State University of Santa Cruz, Ilheus - BA, located on the eastern coast of Brazil, implemented a research program for Tropical Aquatic Systems. As a part of this major program, a series of field campaigns were conducted on the inner shelf between $14^{\circ} 18^{\prime}$ and $15^{\circ} 40^{\prime} \mathrm{S}$. This study describes the distribution of dissolved inorganic nutrients, chlorophyll- $a$ and total suspended solids in the inner portion of the eastern Brazilian continental shelf, and its ecological significance for this oligotrophic environment.

\section{Material And Methods}

Study Area

The study area is located on the eastern Brazilian continental shelf, between the cities of Itacaré and Canavieiras, BA $\left(39^{\circ} 04^{\prime}-38^{\circ} 51^{\prime} \mathrm{W}\right.$ and $14^{\circ} 18^{\prime}-15^{\circ} 40^{\prime} \mathrm{S}$ ) (Fig. 1), and focused on the narrow strip between the coastline and the $40 \mathrm{~m}$ isobath. Transects were drawn perpendicularly to the coast, near Itacaré (close to the Contas River), Ponta do Ramo (Almada River), Ilhéus (Cachoeira River), Olivença and Comandatuba (Una River).

In the oceanographic domain, the continental shelf is influenced by two water masses: the oligotrophic Tropical Water (TW) of the Brazil Current (BC), with temperature above $20^{\circ} \mathrm{C}$ and salinity > 36; and the Coastal Water (CW), warm and with lower salinity $(S<36)$, formed by TW dilution with continental runoff and precipitation (EKAU; KNOPPERS, 1999; SILVEIRA et al., 2000). In this region the wind regime changes along the year by the migration of the divergence zone towards the Equator during summer (as far as $13^{\circ} \mathrm{S}$ ) and southwards in the winter (down to $20^{\circ} \mathrm{S}$ ). These changes lead to the prevalence of trade winds and waves from the northeast (NE) during the summer and winds from the southeast (SE) in the winter. The interactions with the $\mathrm{E}$ winds that blow all year round generate waves from the SE and the winter wave pattern is reinforced by south-southeast (S-SE) winds associated with cold fronts from the South Atlantic. Wave swells from the northeast-east (NE-E) are the major mechanism of vertical mixing in the $20 \mathrm{~m}$ depth zone, while SE and S-SE winds due to cold fronts can act up to $35 \mathrm{~m}$ depth (BITTENCOURT et al., 2000). The tides are also another mixing mechanism. The region presents semi-diurnal frequencies and maximal tidal height of 2.4 m (TESSLER; GOYA, 2005). 


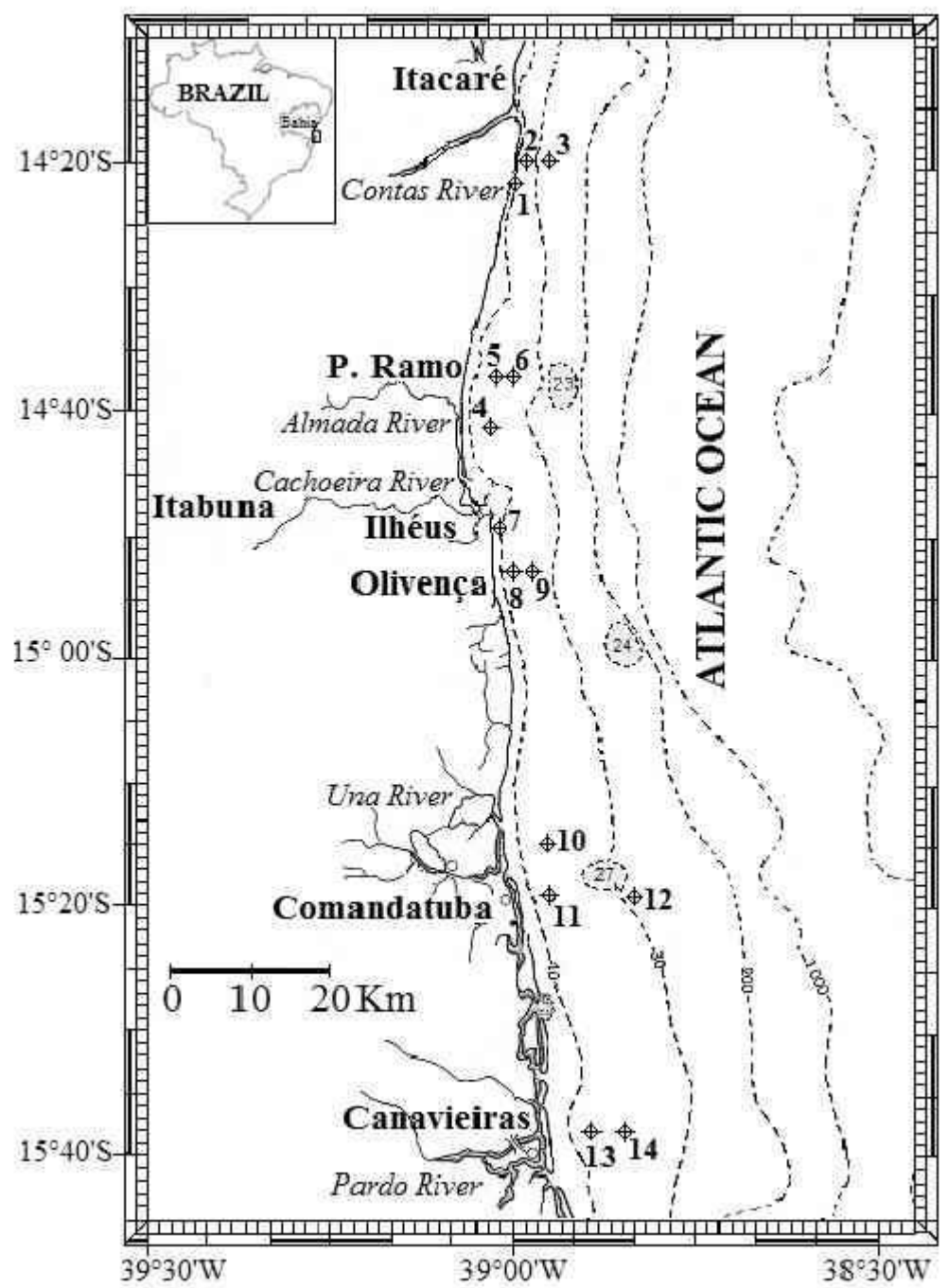

Fig. 1. Map of the study area showing the location of sampling stations on the inner continental shelf between Itacaré and Canavieiras, Bahia. Modified from DHN (2002).

The climate is warm and humid, with a mean monthly temperature of $23^{\circ} \mathrm{C}$ and mean monthly precipitation of about $145 \mathrm{~mm}$ in Itacaré, 144 in Ilhéus and $111 \mathrm{~mm}$ in Canavieiras. The rainy season can occur during summer (November to March) or autumn (April) (BAHIA, 2001), with minimum precipitation from June to August (CRA, 2001). However, this behavior may vary considerably in terms of interannual frequencies. The main continental influence is due to the drainage basins of the Contas River $\left(55,334 \mathrm{~km}^{2}\right)$, Una River $\left(1,280 \mathrm{~km}^{2}\right)$, Pardo River (30,360 km²) (SOUZA; KNOPPERS, 2003), Almada River $\left(1,545 \mathrm{~km}^{2}\right)$ and Cachoeira River $(4,222$ $\mathrm{km}^{2}$ ) (BAHIA, 2001). The Contas and Pardo rivers exhibit the higher mean annual discharges (about 5 and $3 \mathrm{~km}^{3} \mathrm{yr}^{-1}$, respectively). The fluvial discharge of the Una and Cachoeira Rivers accounts for about 0.7 and $0.3 \mathrm{~km}^{3} . \mathrm{yr}^{-1}$, respectively. These rivers receive domestic and industrial effluents and fertilizer residues from the cultivation of crops (SOUZA; KNOPPERS, 2003). The Cachoeira River already shows signs of severe eutrophication (SOUZA, 2005; SILVA et al., 2013).

The study area is also characterized by the presence of small mangrove forests (OVALLE et al., 1999), but although salinity in the narrow coastal strip is controlled by river discharge, the salinity characteristics of the middle and outer shelf indicate the predominant control of the Brazil Current in the region (KNOPPERS et al., 1999). 
Sampling and Chemical Analysis

Water sampling was carried out at 14 points on the inner continental shelf ( $<35 \mathrm{~m}$ depth, Table 1$)$, in three periods: 29-31 March 2006 and 3-6 August 2006 and 23-26 March 2007. Samples from surface $(0.5 \mathrm{~m})$ and near bottom (1.0 $\mathrm{m}$ above bottom) water were taken using a Van Dorn bottle. Dissolved oxygen (DO), salinity and temperature were measured in the field with portable digital meters (Hanna for DO and WTW Multiline P4 for salinity and temperature). Samples were filtered using fiberglass filters of type $\mathrm{GF} / \mathrm{C}$ previously calcinated at $450^{\circ} \mathrm{C}$ and weighed. These filters were used to obtain total suspended solids (TSS) using a gravimetric method (STRICKLAND; PARSONS, 1972). The concentrations of dissolved inorganic nutrients (ammonium, nitrite, nitrate (DIN), and phosphate (DIP)) were determined in accordance with GRASSHOFF et al. (1983), while the silicate (DSi) concentration was established using the method of Carmouze (1994). Chlorophyll- $a$ was analyzed using a spectrophotometric method (PARSONS et al., 1984). The percentage (\%) saturation of DO in the samples was computed by the solubility equations for oxygen in seawater (UNITED STATES, 2011), taking water temperature, salinity and in situ barometric pressure into consideration. The nutrient availability and potential limitation of primary production were estimated by the DIN:DSi:DIP molar ratio and the phytoplankton physiological state by the absorbance ratio (480:665nm) of chlorophyll- $a$ in acetone extract. Ratios lower than 1.73 were found when the phytoplankton was in optimum nutritional state, and ratios above this value indicate limitation by some of the nutrients (HEATH et al., 1990).

\section{RESULTS}

The TS diagram shows the presence of CW and TW (Fig. 2), with dominance of CW on the inner shelf. The differences in the temperature and salinity between surface and bottom indicated a moderate stratified water column (Fig. 3). The temperature and salinity of most samples collected in March and August 2006 characterize the presence of TW. Significant differences were found between surface and bottom, with higher temperature in the surface and higher salinity in the bottom layers (Kruskal Wallis, $p<0.05)$. The average water density at the surface was $1,023 \pm 0.038,1,024 \pm 0.079$ and 1,022 \pm 0.062 $\mathrm{kg} \mathrm{m}^{-3}$, in March 2006, August 2006 and March 2007, respectively. At the bottom, the average density was $1,024 \pm 0.036,1,025 \pm 0.033$ and $1,023 \pm 0.088$ $\mathrm{kg} \mathrm{m}^{-3}$, in March 2006, August 2006 and March 2007, respectively.

Concentrations of DO (measured only in March 2007) varied from 3.22 to $11.0 \mathrm{mg} \mathrm{L}^{-1}$ (Table 2, Fig. 3), corresponding to 63 to $209 \%$ saturation, respectively. These concentrations were significantly higher in bottom waters (Kruskal-Wallis, $p<0.05$ ), which were slightly colder than the surface ones. Concentrations lower than $3.6 \mathrm{mg} \mathrm{L}^{-1}$ were measured at the stations near the locations of Ponta do Ramo, Olivença and Comandatuba (Fig. 3). DO supersaturation was observed in the sampling stations near Canavieiras $(111-209 \%)$ where mixing in the coastal zone plays an important role.

Table 1. Coordinates and sampling distance of the points in the regions on the continental shelf, between Itacare and Canavieiras. Surface sampling depth was $0.5 \mathrm{~m}$.

\begin{tabular}{|c|c|c|c|c|c|}
\hline \multirow[t]{2}{*}{ Coastal region } & \multirow{2}{*}{$\begin{array}{l}\text { Sampling } \\
\text { point (\#) }\end{array}$} & \multicolumn{2}{|c|}{ Coordinates } & \multirow{2}{*}{$\begin{array}{c}\text { Bottom sampling } \\
\text { depth (m) }\end{array}$} & \multirow{2}{*}{$\begin{array}{l}\text { Distance from the } \\
\text { coast }(\mathrm{km})\end{array}$} \\
\hline & & Latitude (S) & Longitude (W) & & \\
\hline \multirow[t]{3}{*}{ Itacaré } & 1 & $14^{\circ} 22.586^{\prime}$ & $39^{\circ} 00.133^{\prime}$ & - & 1 \\
\hline & 2 & $14^{\circ} 20.347^{\prime}$ & $38^{\circ} 59.352^{\prime}$ & 16 & 3 \\
\hline & 3 & $14^{\circ} 20.486^{\prime}$ & $38^{\circ} 57.557^{\prime}$ & 34 & 5 \\
\hline \multirow[t]{3}{*}{ P. Ramo } & 4 & $14^{\circ} 42.468^{\prime}$ & $39^{\circ} 03.245^{\prime}$ & - & 3 \\
\hline & 5 & $14^{\circ} 37.745^{\prime}$ & $39^{\circ} 02.590^{\prime}$ & 16 & 4 \\
\hline & 6 & $14^{\circ} 37.745^{\prime}$ & $39^{\circ} 00.630^{\prime}$ & 24 & 6.5 \\
\hline \multirow[t]{3}{*}{ Olivença } & 7 & $14^{\circ} 49.498^{\prime}$ & $39^{\circ} 01.093^{\prime}$ & - & 1.5 \\
\hline & 8 & $14^{\circ} 53.023^{\prime}$ & $39^{\circ} 00.230^{\prime}$ & 11 & 3.5 \\
\hline & 9 & $14^{\circ} 53.070^{\prime}$ & $38^{\circ} 58.714^{\prime}$ & 21 & 5.5 \\
\hline \multirow[t]{3}{*}{ Comandatuba } & 10 & $15^{\circ} 14.560^{\prime}$ & $38^{\circ} 58.010^{\prime}$ & - & 6 \\
\hline & 11 & $15^{\circ} 19.320^{\prime}$ & $38^{\circ} 57.693^{\prime}$ & 11 & 4 \\
\hline & 12 & $15^{\circ} 19,325^{\prime}$ & $38^{\circ} 51.735^{\prime}$ & 32 & 15 \\
\hline \multirow[t]{2}{*}{ Canavieiras } & 13 & $15^{\circ} 38.480^{\prime}$ & $38^{\circ} 53.425^{\prime}$ & 11 & 6 \\
\hline & 14 & $15^{\circ} 38.485^{\prime}$ & $38^{\circ} 50.080^{\prime}$ & 19 & 10 \\
\hline
\end{tabular}



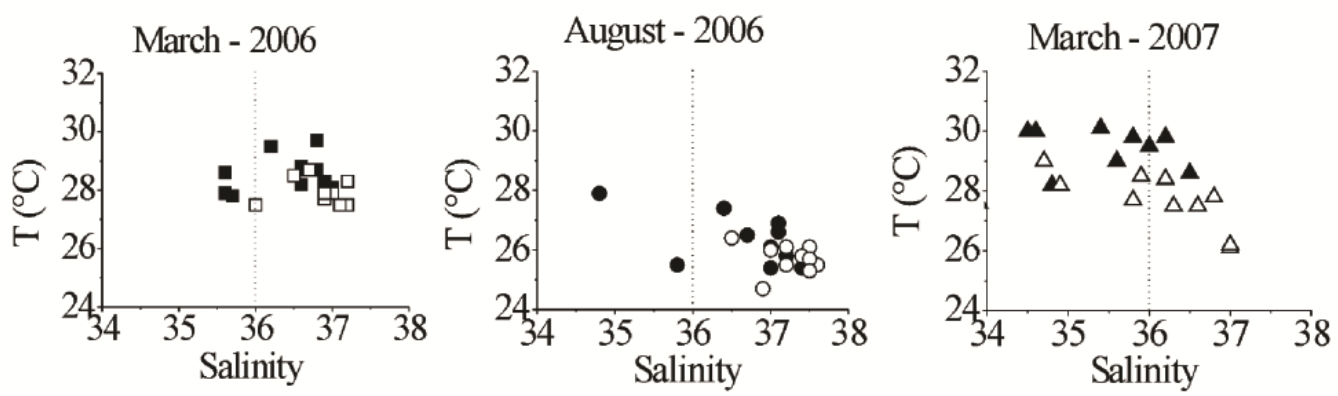

Fig. 2. T S plot of sampling surveys. Closed and open symbols represent surface and bottom samples; dashed line separates CW (left) from TW (right).
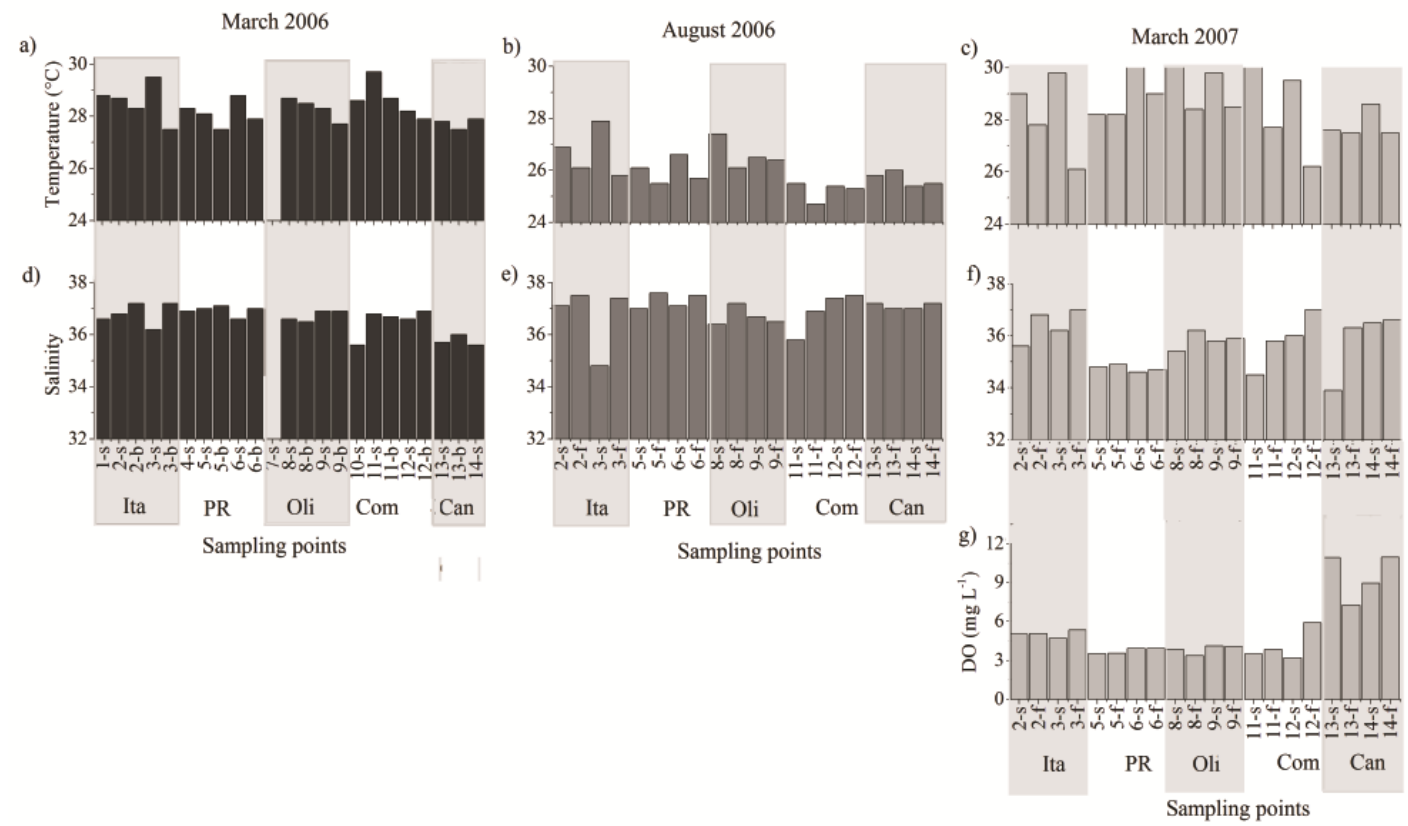

Fig. 3. Temperature, salinity and dissolved oxygen (DO) at the surface (s) and bottom (b).

TSS and Chl $-a$ concentrations ( 0.34 to 783 $\mathrm{mg} \mathrm{L}^{-1}$ and 0.08 to $5.79 \mathrm{mg} \mathrm{L}^{-1}$, respectively, Fig. 4) were also higher in bottom waters (Kruskal-Walis, $p<$ 0.05), especially in August, showing a positive and significant correlation (Fig. 5). The higher TSS value observed (Comandatuba station 11, bottom) was noted visually in the sampling bottle, and the van Dorn was launched again twice to ensure it was not due to resuspension caused by the sampling method.

Dissolved silica concentrations in March (Fig. 4g) and August (Fig. 4h) 2006 were higher in the coastal region of Ponta do Ramo, Comandatuba and Canavieiras. In March 2007, silicate values were higher at the surface at stations closer to the coast and also at the bottom of the deeper stations (Fig. 4i). Nitrate concentrations were below $1.00 \mathrm{mmol} \mathrm{L}^{-1}$, except at the surface at station 9 in March 2006 (1.83 mmol L $\mathrm{L}^{-1}$ ) and at the bottom at station 11 in August 2006 (1.00 mmol $\mathrm{L}^{-1}$ ) (Fig. 6). The nitrate concentration was significantly higher in surface than bottom waters in March 2006 (Kruskal Wallis, $p<$ 0.05). Nitrite was below the detection limit in all samples and ammoniacal nitrogen concentrations were higher in March 2006 and 2007, especially in the Itacaré and Comandatuba regions. Phosphate concentrations were higher in the south of the study area, in Comandatuba and Canavieiras during August 2006 (Fig. 6h) and March 2007 (Fig. 6i). Higher concentrations were also observed in bottom waters in March 2006 (station 3, $0.60 \mathrm{mmol} \mathrm{L}^{-1}$ ) and August 2006 (station 9, $0.41 \mathrm{mmol} \mathrm{L}^{-1}$ ) 

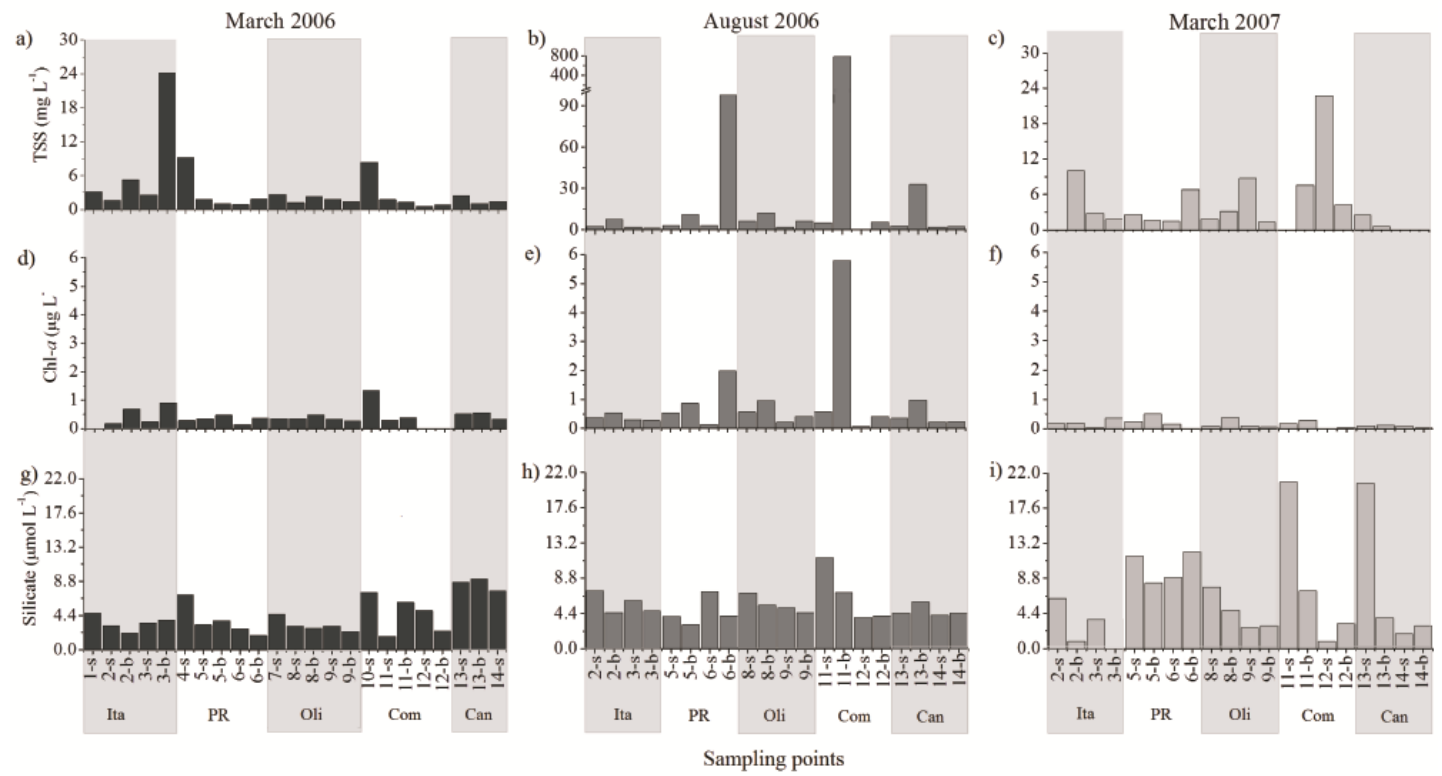

Fig. 4. TSS, chlorophyll- $a$ and silicate concentrations.

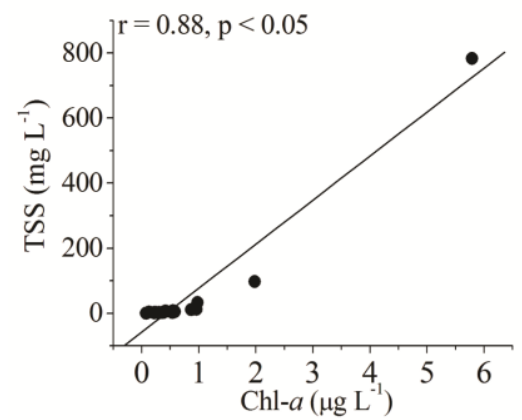

Fig. 5. Spearman correlation between TSS and Chl- $a$ in winter 2006.
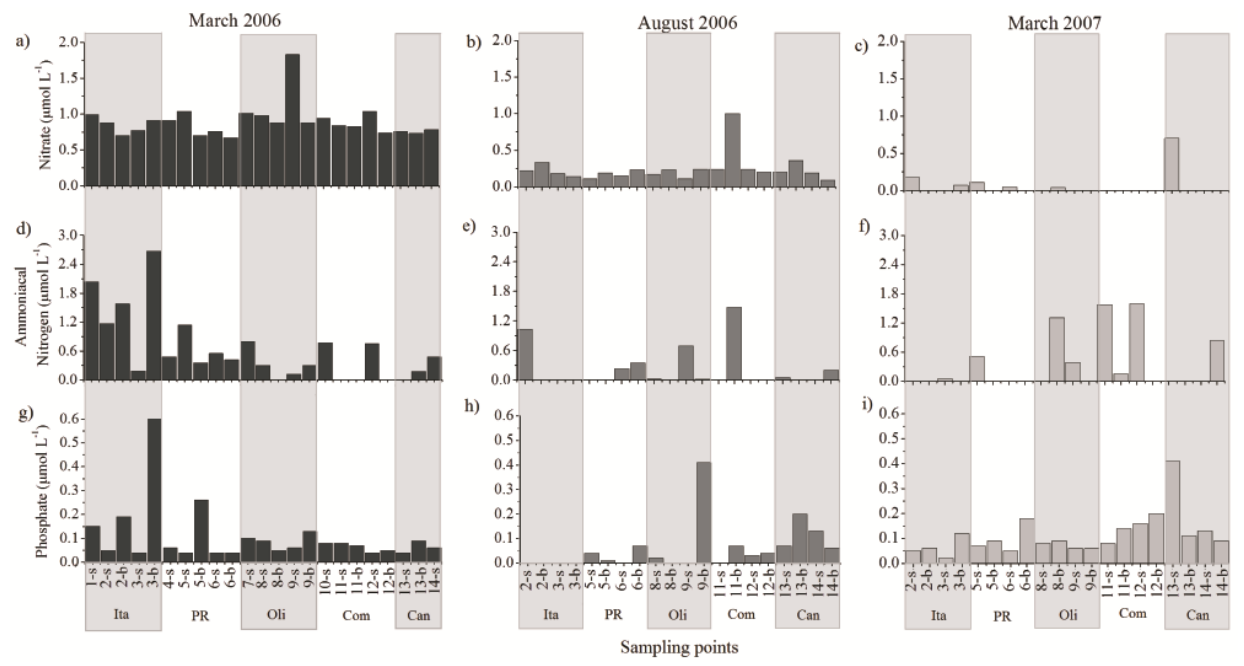

Fig. 6. Nitrate, ammoniacal nitrogen and phosphate concentrations in surface (s) and bottom (b). 
Molar ratio DIN: DIP (Fig. 7a) showed high variability, from 4 to 60 in March 2006, with values higher than 16 in most samples. In August 2006 and March 2007 there was a predominance of DIN: DIP ratios lower than 16 . The DIN:DSi ratios were usually below 1:1 during the three surveys (Fig. 7b) and most of the samples showed a DSi:DIP ratio higher than 16 (Fig. 7c).

The ratio of 480:665 absorbance varied from 1.1 and 4.5 in March 2006, from 1.7 to 7.7 in August 2006, and between 1.4 and 3.7 in March 2007 (Fig. 7d).
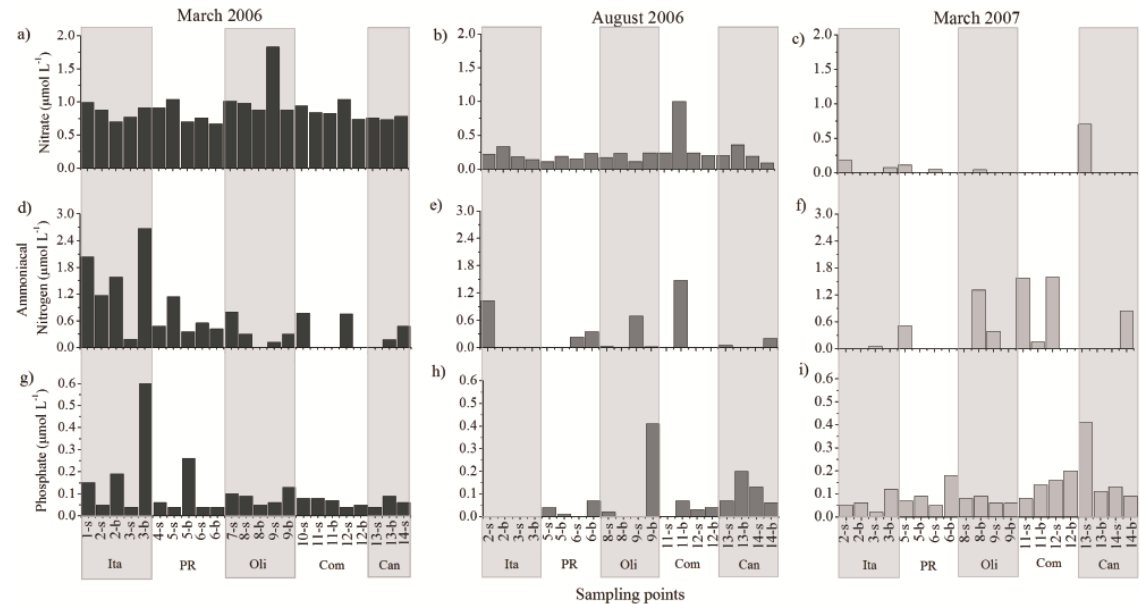

Fig. 6. Nitrate, ammoniacal nitrogen and phosphate concentrations in surface (s) and bottom (b).

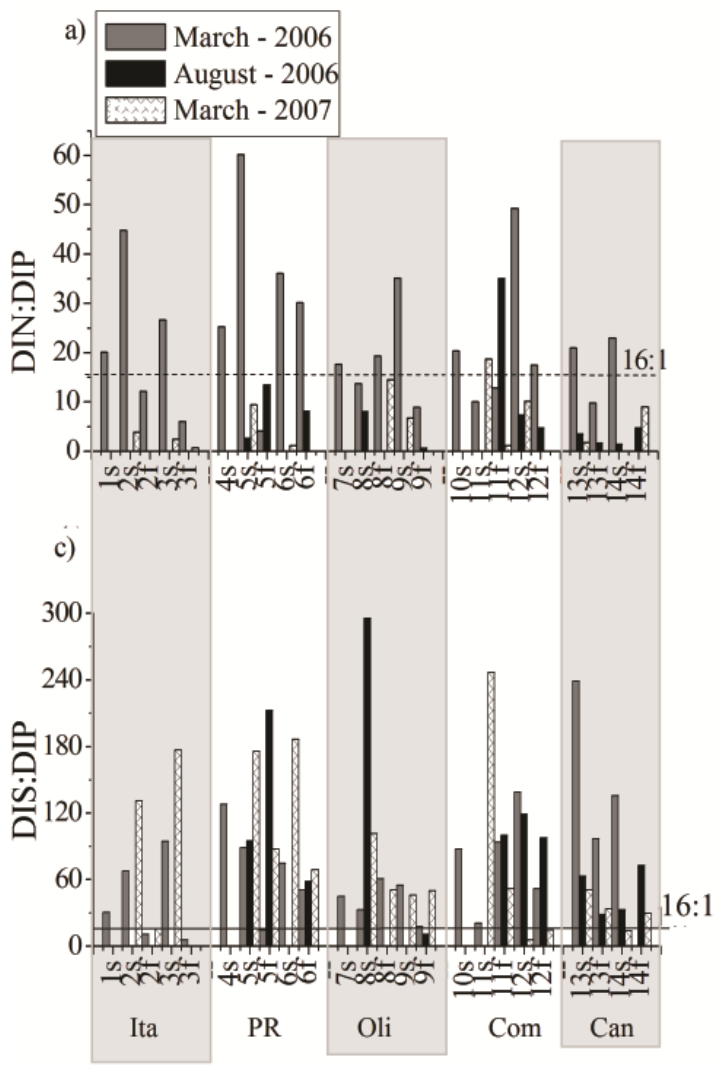

b)

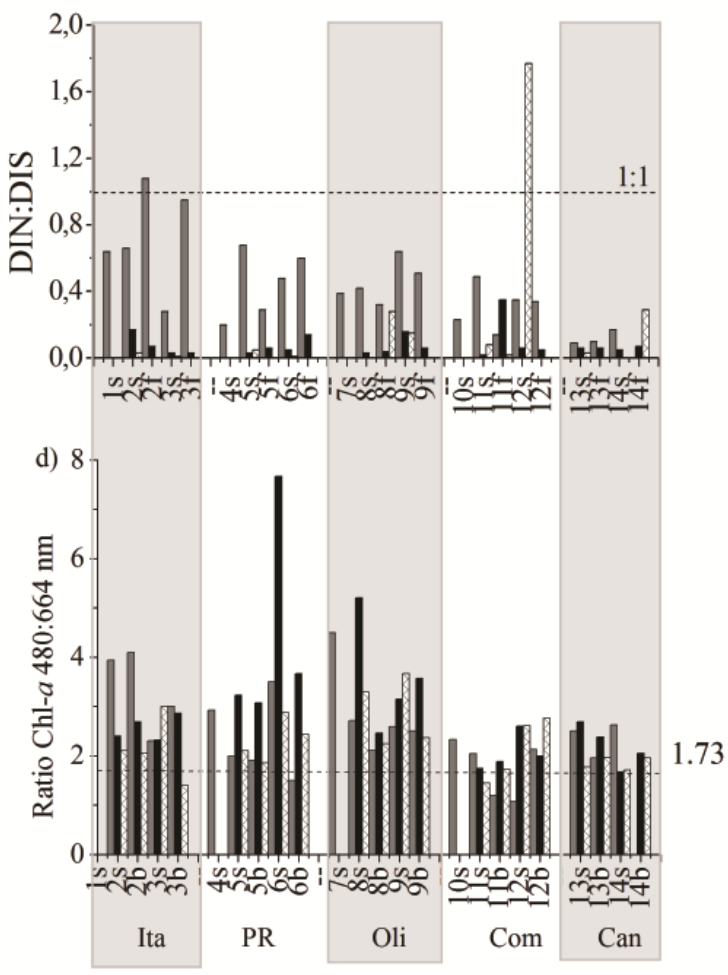

Sampling points

Fig. 7. Molar ratios (a) DIN:DIP, (b) DIN:DSi, (c) DSi:DIP and (d) ratio 480:665 nm. Dash line indicates Redfield ratio. 


\section{Discussion}

There was no evidence of upwelling at any of the stations, but the results suggest the intrusion of colder (March 2006 and 2007) and saltier (all surveys) water at the bottom. The concentrations of DO in summer 2007 were usually similar to those found on tropical continental shelves (GIANESELLA; SALDANHA-CORRÊA, 2003; LUGIOYO et al., 2007; PEDROSA et al., 2006; Table $2)$. Bottom water was significantly enriched in DO, TSS, Chl- $a$ and nitrate. The higher salinity and nutrient, Chl- $a$ and TSS concentrations at the bottom occurred independently of the year and season (summer or winter). This suggests that sediment resuspension driven by strong winds and tidally induced waves can control the distribution and availability of nutrients in the water as well as having an impact on Chl- $a$ and TSS in the water column. However, the concentrations of nitrate, phosphate and ammoniacal nitrogen found in this study were typical of the TW carried by the Brazil Current (KNOPPERS et al., 1999).
Another scenario considered is the influence of the intrusion of colder and nutrient rich waters on the shelf and mixing with TW to form a Shelf Water with slightly higher concentrations of major nutrients. Pereira et al (2005) also suggested a strong influence of tidally induced vertical displacements on the eastern Brazilian shelf, which can enhance vertical mixing at the shelf break and injects cold waters into the bottom layer on the continental shelf. Amorim et al. (2011) related the occurrence of resurgence at the eastern Brazilian shelf break $\left(13^{\circ} \mathrm{S}\right.$, southward of Todos os Santos Bay), during summer 2007. Prevailing East and Northeast winds associated with the topography of shelf canyons, promoted a southward narrow current inducing upwelling on the inner continental shelf. In the study area, two submarine canyons (in front of Contas and Almada rivers) reach the inner shelf (FREIRE; DOMINGUEZ, 2006). The narrow shelf in this region and the presence of these canyons can favor the TW intrusion onto the shelf, as well as cold water at the bottom on the shelf, inducing the composition of inner shelf waters, and in consequence, leading to the formation of a deep chlorophyll maximum (BRANDINI et al., 2013).

Table 2. Minimum - maximum, mean \pm standard deviation of the physico-chemical and biological variables in continental shelf waters. The two first lines show the results of the present study.

\begin{tabular}{|c|c|c|c|c|c|c|c|c|c|}
\hline Region & Salinity & $\begin{array}{c}\mathrm{T} \\
\left({ }^{\circ} \mathrm{C}\right)\end{array}$ & $\begin{array}{c}\text { DO } \\
\left(\mathrm{mg} \mathrm{L}^{-1}\right)\end{array}$ & $\begin{array}{c}\text { TSS } \\
\left(\mathrm{mg} \mathrm{L}^{-1}\right)\end{array}$ & $\begin{array}{c}\text { Chl- } a \\
\left(\mu \mathrm{g} \mathrm{L}^{-1}\right)\end{array}$ & $\begin{array}{c}\mathrm{N}^{-\mathrm{NO}_{3}^{-}} \\
\left(\mu \mathrm{mol} \mathrm{L}{ }^{-1}\right)\end{array}$ & $\begin{array}{c}\mathrm{N}-\mathrm{NH}_{4}^{+} \\
\left(\mu \mathrm{mol} \mathrm{L}{ }^{-1}\right)\end{array}$ & $\begin{array}{c}{\mathrm{P}-\mathrm{PO}_{4}{ }^{3-}}^{\left(\mu \mathrm{mol} \mathrm{L}{ }^{-1}\right)}\end{array}$ & 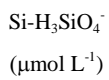 \\
\hline $\begin{array}{l}{ }^{\mathrm{a}} \text { Eastern } \\
\text { Brazilian inner } \\
\text { continental shelf }\end{array}$ & $33.9-37.6$ & $24.7-30.1$ & $3.22-11.0$ & $0.34-783$ & $<1 . d-5.79$ & $<1 . d-1.83$ & $<1 . d-2.67$ & $<1 . d-0.60$ & $<1 . d-20.9$ \\
\hline $\begin{array}{l}{ }^{\mathrm{b}} \text { Eastern } \\
\text { Brazilian coast }\end{array}$ & - & - & - & - & $0.40 \pm 0.40$ & $0.53 \pm 0.48$ & $1.10 \pm 0.27$ & $0.51 \pm 0.32$ & $1.81 \pm 0.94$ \\
\hline $\begin{array}{l}{ }^{\mathrm{c}} \text { Eastern } \\
\text { Brazilian coast }\end{array}$ & - & - & - & - & $<0.5$ & $<0.20$ & - & $<0.08$ & - \\
\hline $\begin{array}{l}{ }^{\mathrm{d}} \text { Eastern } \\
\text { Brazilian coast of } \\
\text { Abrolhos }\end{array}$ & - & - & - & $8.75 \pm 17.0$ & - & - & - & - & $3.42 \pm 1.19$ \\
\hline $\begin{array}{l}{ }^{\mathrm{e}} \text { Continental } \\
\text { shelf of } \\
\text { Pernambuco }\end{array}$ & - & - & - & - & $0.31-7.95$ & - & - & - & - \\
\hline $\begin{array}{l}{ }^{\mathrm{f}} \text { Inner continental } \\
\text { shelf of São } \\
\text { Sebastião }\end{array}$ & $34.6 \pm 0.95$ & $25.7 \pm 2.87$ & $4.62 \pm 0.38$ & $24.4 \pm 15.8$ & $0.48 \pm 0.41$ & $1.55 \pm 1.28$ & $0.71 \pm 0.55$ & $0.15 \pm 0.11$ & $4.14 \pm 1.89$ \\
\hline $\begin{array}{l}{ }^{\mathrm{g}} \text { Cuban southern } \\
\text { oceanic waters }\end{array}$ & $36.3-36.7$ & $25,9-29,5$ & & & & $* 0.14-4.73$ & & $0.08-0.29$ & \\
\hline $\begin{array}{l}\text { h } \text { Mediterranean } \\
\text { coastal }\end{array}$ & $36.6-37.6$ & & $6.0-10.6$ & $4-60$ & $0.2-9.2$ & $0.06-7.87$ & $0.05-1.70$ & $0.001-0.23$ & $0.70-9.41$ \\
\hline
\end{tabular}

$* \mathrm{~N}-\mathrm{NO}_{3}+\mathrm{N}-\mathrm{NO}_{2}{ }^{-}$

${ }^{\mathrm{a}}$ This study; ${ }^{\mathrm{b}}$ OVALLE et al., $1999 ;{ }^{\mathrm{c}}$ EKAU and KNOPPERS, $1999 ;{ }^{\mathrm{d}}$ LEIPE et al., $1999 ;{ }^{\mathrm{e}}$ PASSAVANTE and FEITOSA, $1995 ;{ }^{\mathrm{f}}$ GIANESELLA and SALDANHA-CORREAA, 2003; ${ }^{\mathrm{g}}$ LUGIOYO et al., 2007; ${ }^{\mathrm{h}}$ SEBASTIÁ and RODILLA, 2013. 
The dissipation of internal waves could lead to a high current shear and vertical mixing in the shallower shelf water (SHARPLES et al., 2007; PEREIRA et al, 2005). The turbulent mixing in these shallow waters could also be promoted by winds, but during the sampling periods, the winds ranged from weak $\left(0.5-5.2 \mathrm{~m} \mathrm{~s}^{-1}\right)$ to moderate $\left(\sim 5.7 \mathrm{~m} \mathrm{~s}^{-1}\right)$ and sea conditions suggested that fetch and wind intensity were not enough to promote a complete vertical mixing. The lower concentrations and DO subsaturation observed in surface waters between Ponta do Ramo and Canavieiras are probably related to organic matter content of continental origin rather than to lower oxygen solubility. Intense precipitation was observed in the region of Ilhéus a few days before the March 2007 campaign and fluvial inputs were considerable in that season, as evidenced by the high TSS and low salinity in adjacent coastal waters. Increased inputs from the eutrophic Cachoeira River estuary were reported during episodic torrential discharge, carrying large amounts of the macrophyte Eichornia crassipes to the coastal waters (FIDELMAN, 2005; SOUZA, 2005). The remineralization of this organic matter might influence the physico-chemical characteristics of coastal waters in very localized and episodic events. Values of temperature, salinity, Chl- $a$ and dissolved inorganic nutrients in most samples were similar to those found on the oligotrophic eastern Brazilian coast (EKAU; KNOPPERS, 1999; LEIPE et al., 1999; SUSINI-RIBEIRO, 1999) and other tropical continental shelves (PASSAVANTE; FEITOSA, 1995; BURFORD; ROTHLISBERG, 1999; OVALLE et al., 1999; GIANESELLA; SALDANHA-CORRÊA, 2003; ZELDIS, 2004; PEDROSA et al., 2006; SIGNORET et al., 2006; LUGIOYO et al., 2007; SEBASTIÁ; RODILLA, 2013) (Tab. 2). The low concentrations of dissolved inorganic nutrients and Chl- $a$ denote the influence of oligotrophic TW over the entire shelf. These low nutrient values are also the result of assimilation not only by phytoplankton and other primary producers but also by microheterotrophs (OVALLE et al., 1999).

The results found in this study indicate that low nutrient concentrations, especially at the surface, can be limiting for phytoplankton production. The ratio 480/665 $\mathrm{nm}$ exceeded 1.73 in most samples, indicating nutritional deficiency. Molar ratios higher than Redfield's were found in March 2006, and lower than 16 in August 2006 and March 2007. These values below 16 indicate limitation by nitrogen, and are another evidence of the influence of TW in the inner shelf waters. However N:P molar ratios varied within a wide range, probably due to the circulation processes of the shelf waters, mixing $\mathrm{CW}$ and $\mathrm{TW}$ waters, again showing the importance of oceanographic events that drive vertical mixing and advection of waters along the inner shelf.

Silicate concentrations were high, but similar to those observed by Leipe et al. (1999) in the Abrolhos region $\left(\sim 17^{\circ} \mathrm{S}\right.$, Brazil). The great availability of silicate resulted in DIN:DSi ratios lower than 1 and DSi:DIP higher than 16. On the Canavieiras transect, in the south of the area, the silicate concentrations were higher than those described by Ovalle et al. (1999) in the same region. Souza et al. (2003) estimated that the River Pardo (Canavieiras) and Cachoeira (Ilhéus) are the main sources of silicate to coastal waters in this region. A coastal drift and inner shelf eddies may spread silicate enriched CW northward, under the influence of waves and wind. Despite the continental inputs from small rivers and estuaries, the inner shelf still presents oligotrophic characteristics and high heterogeneity, probably due to vertical stratification and the influence of $\mathrm{CB}$ driving TW intrusions over the shelf, together with a northward drift caused by winds and waves transporting $\mathrm{CW}$ and mixing it with TW to form shelf waters.

\section{Conclusions}

This study contributed to knowledge of the biogeochemical characteristics of an oligotrophic marine tropical system, the inner portion of the narrow eastern Brazilian continental shelf. This region is dominated by nutrient poor Tropical Waters during the periods of low continental drainage, but with strong influence of Coastal Waters and higher nutrient concentrations when continental inputs increase (March 2007). The water column is mainly stratified, with the intrusion of colder and saltier waters at the bottom due to an oceanographic shelf border process. Despite the presence of several sources of continental inputs, nutrient and chlorophyll- $a$ concentrations were characteristic of oligotrophic waters, but with high spatial heterogeneity. Nitrogen seems to be the main limiting nutrient to phytoplankton primary production, although vertical stratification and horizontal mixing of CW and TW along the coast, and other shelf processes introduce heterogeneity and complexity to this system.

\section{AcKNowledgements}

The authors wish to thank Dr. Gecely R. A. Rocha (UESC) for the opportunity to participate in the sampling surveys of the project ECOCAM (Exploração e conservação da fauna acompanhante na pesca do camarão entre Itacaré e Canavieiras, Bahia, CNPq APQ Proc. No. 473312/2004-2), as also the 
staff of the Laboratório de Oceanografia Química and Laboratório de Oceanografia Biológica of UESC for their assistance in sampling and chemical analysis, especially Dr. Fernanda J. Guimarães and MSc. Ricardo O’Reilly Vasques. They would also thank Dr. Gil M.R. Strenzel and Dr. Daniela M.L. da Silva (UESC) for their valuable comments on an earlier draft. The authors also acknowledge two anonymous referees for their suggestions. The first author expresses his gratitude to the Fundação de Amparo à Pesquisa do Estado da Bahia (FAPESB) for the M.S. grant process no. BOL1088/2007.

\section{REFERENCES}

AMORIM, F. N.; CIRANO, M.; SOARES, I. D.; CAMPOS, E. J. D.; MIDDLETON, J. F. The influence of largescale circulation, transient and local processes on the seasonal circulation of the Eastern Brazilian Shelf, $13^{\circ} \mathrm{S}$. Cont. Shelf Res., v. 32, p. 47-61, 2012.

ADMIRAAL, W.; BREUGEM, P.; JACOBS, D. M. L. H. A.; DE RUYTER VAN STEVENINCK, E. D. Fixation of dissolved silicate and sedimentation of biogenic silicate in the lower river Rhine during diatom blooms. Biogeochemistry, v. 9, n. 2, p. 175-185, 1990.

BAHIA (Estado). Superintendência de Recursos Hídricos. Programa de recuperação das bacias dos rios cachoeira e almada: diagnóstico regional, caracterização climatológica. Ilhéus: SRH/UESC, 2001. v. 1 , t. III, 86 p.

BERGER, W. H.; SIEDLER, G.; WEBB, D. J. (Eds.). The South Atlantic: present and past circulation. Berlin: Springer, 1996. $644 \mathrm{p}$.

BITTENCOURT, A. C. S. P.; DOMINGUEZ, J. M. L.; MARTIN, L.; SILVA, I. R. Patterns of sediment dispersion coastwise the State of Bahia - Brazil. An. Acad. Bras. Cienc., v. 72, n. 2, p. 271-287, 2000.

BRANDINI, F. P.; NOGUEIRA Jr., M.; SIMIÃO, M.; CODINA, J. C. U.; NOERNBERG, M. A. Deep chlorophyll maximum and plankton community response to oceanic bottom intrusions on the continental shelf in the South Brazilian Bight. Cont. Shelf Res., 2013. [In press].

BURFORD, M. A.; ROTHLISBERG, P. C. Factors limiting phytoplankton production in a tropical continental shelf ecosystem. Estuarine, Coastal Shelf Sci., v. 48, n. 5, p. 541-549, 1999.

CARMOUZE, J. P. O metabolismo dos ecossistemas aquáticos: fundamentos teóricos, métodos de estudo e análises químicas. São Paulo: Edgar Blücher, 1994. chap. 10.

SEIRH. Sistema Estadual de Informações de Recursos Hídricos. Programa Monitora. Available in: http://monitora.inema.ba.gov.br/index.php/pontos/relator iopontos. Accessed on: Aug. 3, 2007.

DHN. Marinha do Brasil. Costa Leste de Recife a Belmonte. 2002. 3.ed. 60

FREIRE, A. F. M.; DOMINGUEZ, J. M. L. A seqüência holocênica da plataforma continental central do Estado da Bahia. Bol. Geocienc. Petrobras, v. 14, n. 2, p. $247-$ 267, 2006.
EKAU, W.; KNOPPERS, B. An introduction to the pelagic system of the North-East and East Brazilian shelf. Arch. Fish. Mar. Res., v. 47, n. 2/3, p. 113-125, 1999.

FIDELMAN, P. I. J. Contribuição para mitigação dos impactos da macrófita aquática Eichhornia Crassipes sobre a zona costeira da Região Sul da Bahia. Gestão Costeira Integr., v. 4, p. 1-5, 2005.

GIANESELLA, S. M. F.; SALDANHA-CORRÊA, F. M. P. Nutrientes, séston e biomassa fitoplanctônica na plataforma interna de São Sebastião - verão de 1994 e primavera de 1997. Bol. Inst. Pesca, v. 29, n. 2, p. 161$172,2003$.

GRASSHOFF, K.; EHRARDT, M.; KREMLING, K. (Eds.). Methods of seawater analysis. 2.ed. Wheinhein: Deefield Beach; Basel: Verlag Chermie, 1983. 419 p.

HEATH, M. R.; RICHARDSON, K.; KIORBOE, T. Optical assessment of phytoplankton nutrient depletion. J. Plankton Res., v. 12, n. 2, p. 381-396, 1990.

JENNERJAHN, T.; KNOPPERS, B. A.; SOUZA, W. F. L.; CARVALHO, C. E.; MOLLENHAUER, G.; HÜBNER, M.; ITTEKKOT, V. The tropical Brazilian continental margin. In: LIU, K. -K.; ATKINSON, L.; QUINONES, R.; TALAUE-MCMANUS, L. (Org.). Carbon and nutrient fluxes in continental margins: a global synthesis. Berlin: Springer Verlag, 2010. p. 427-442. (Global change--the IGBP series).

KNOPPERS, B.; EKAU, W.; FIGUEIREDO, A. G. The coast and shelf of East and Northeast Brazil and material transport. Geo-Mar. Lett., v. 19, n. 3, p. 171-178, 1999.

LEIPE, T.; KNOPPERS, B.; MARONE, E.; CAMARGO, R. Suspended matter transport in coral reef waters of the Abrolhos Bank, Brazil. Geo-Mar. Lett., v. 19, n. 3, p. 186-195, 1999.

LUGIOYO, G. M.; LOZA, S.; ABREU, P. C. Biomass distribution of heterotrophic and autotrophic microorganisms of the photic layer in Cuban southern oceanic waters. Rev. Biol. Trop., v. 55, n. 2, p. 449-457, 2007.

MANN, K. H.; LAZIER, J. R. N. Dynamics of marine ecosytems: biological-physical interactions in the oceans. 2.ed. Cambridge: Oxford: Blackwell Science, 1996. $394 \mathrm{p}$.

MARONE, E.; KNOPPERS, B. A.; SOUZA, W. F. L.; SILVEIRA, I. C.; GODOI, S. S. The Brazil current: physical-biogeochemical domains. In: KON-KEE, L; ATKINSON, L.; QUINONES, R.; TALAUEMCMANUS, L. (Eds.). Carbon and nutrient fluxes in continental margins: a global synthesis. Berlin: Springer Verlag, 2010. v. 1, p. 153-170. (Global change-the IGBP series).

OVAllE, A. R. C.; REZENDE, C. E.; CARVALHO, C. E. V.; JENNERJAHN, T. C.; ITTEKKOT, V. Biogeochemical characteristics of coastal waters adjacent to small river-mangrove systems, East Brazil. Geo-Mar. Lett., v. 19, n. 3, p. 179-185, 1999.

PARSONS, T. R.; MAITA, Y.; LALLI, C. M. A manual of chemical and biological methods for seawater analysis. 2.ed. Oxford: New York: Pergamon Press, 1984. chap. 4. (Pergamon international library of science, technology, engineering and social studies).

PASSAVANTE, J. Z. O.; FEITOSA, F. A. N. Produção primária do fitoplâncton da plataforma continental de Pernambuco (Brasil): área de Piedade. Bol. Tec. Cient. CEPENE, v. 3, n. 1, p. 7-22, 1995. 
PEDROSA, P.; PARANHOS, R.; SUZUKI, M. S.; ANDRADE, L.; SILVEIRA, I. C. A.; SCHMIDT, A. C. K.; FALCÃO, A. P.; LAVRADO, H. P.; REZENDE, C. E. Hidroquímica de massas d'água oceânicas em regiões da margem continental brasileira, Bacia de Campos, Estado do Rio de Janeiro, Brasil. Geochim. Bras., v. 20, n. 1, p. 101-119, 2006.

PEREIRA, A. F.; BELEM, A. L.; CASTRO, B. M.; GEREMIAS. R. Tide-topography interaction along the Eastern Brazilian shelf. Cont. Shelf Res., v. 25, n. 12/13, p. 1521-1539, 2005.

SÁNCHEZ-ARCILLA, A.; SIMPSON, J. H. The narrow shelf concept: couplings and fluxes. Cont. Shelf Res., v. 22, n. 2, p. 153-172, 2002.

SEBASTIÁ, M. T.; RODILlA, M. Nutrient and phytoplankton analysis of a Mediterranean Coastal area. Environ. Manage., v. 51, n. 1, p. 225-240, 2013.

SHARPLES, J.; TWEDDLE, J. F.; GREEN, J. A. M.; PALMER, M. R.; KIM, Y. N.; HICKMAN, A. E.; HOLLIGAN, P. M.; MOORE, C. M.; RIPPETH, T. P.; SIMPSON, J. H.; KRIVTSOV, V. Spring-neap modulation of internal tide mixing and vertical nitrate fluxes at a shelf edge in summer. Limnol. Oceanogr., v. 52, n. 5, p. 1735-1747, 2007.

SIGNORET, M.; MONREAL-GÓMEZ, M. A.; ALDECO, J.; SALAS-DE-LEÓN, D. A. Hydrography, oxygen saturation, suspended particulate matter, and chlorophyll$a$ fluorescence in an oceanic region under freshwater influence. Estuarine, Coastal Shelf Sci., v. 69, n. 1/2, p. 153-164, 2006.

SILVA, M. A. M.; EÇA, G. F.; SANTOS, D. F.; GUIMARÃES, A. G.; LIMA, M. C.; SOUZA, M. F. L. Dissolved inorganic nutrients and chlorophyll $\mathrm{a}$ in an estuary receiving sewage treatment plant effluents: Cachoeira River estuary (NE Brazil). Environ. Monit. Assess., v. 185, n. 7, p. 5387-5399, 2013.

SILVEIRA, I. C. A.; SCHIMIDT, A. C. K.; CAMPOS, E. J. D.; GODOI, S. S.; IKEDA, Y. A corrente do Brasil ao largo da Costa Leste Brasileira. Rev. Bras. Oceanogr., v. 48, n. 2 , p. $171-183,2000$.

SOUZA, W. F. L.; KNOPPERS, B. A. Fluxos de água e sedimentos a costa Leste do Brasil: relações entre a tipologia e as pressões antrópicas. Geochim. Bras., v. 17, n.1, p. 57-74, 2003.
SOUZA, W. F. L.; KNOPPERS, B. A.; BALZER, W.; LEIPE, T. Geoquímica e fluxos de nutrientes, ferro e manganês a costa Leste do Brasil. Geochim. Bras., v. 17, n.2, p. 130-144, 2003.

SOUZA, M. F. L. Nutrient biogeochemistry and mass balance of a tropical Estuary of Cachoeira River, Northern Brazil. Int. J. Ecol. Environ. Sci., v. 31, n. 3, p. $177-188,2005$.

STRICKLAND, J. D. H.; PARSONS, T. R. A pratical handbook of seawater analysis. 2.ed. Ottawa: Fishery Research Board Canada, 1972. 311 p. (Fishery Research Board Canada. Bulletin; 167).

SUSINI-RIBEIRO, S. M. M. Biomass distribution of pico-, nano- and microplankton on the continental shelf of Abrolhos East Brazil. Arch. Fish. Mar. Res., v. 47, n. 2/3, p. 271-284, 1999.

TESSLER, M. G.; GOYA, S. C. Processos costeiros condicionantes do Litoral Brasileiro. Rev. Dep. Geogr., v. 17, p.11-23, 2005.

TURNER, R. E.; RABALAIS, N. N. Coastal eutrophication near the Mississippi River delta. Nature, v. 368, n. 6472, p. 619-621, 1994.

UNITED STATES. Geological Survey. Office of Water Quality Technical Memorandum 2011.03: change to solubility equations for oxygen in water. Available in: http://water.usgs.gov/admin/memo/QW/qw11.03.pdf. 2011. Accessed on: July 15, 2011.

ZELDIS, J. R. New and remineralised nutrient supply and ecosystem metabolism on the Northeastern New Zealand continental shelf. Cont. Shelf Res., v. 24, n. 4/5, p. 563$581,2004$.

(Manuscript received 05 October 2012; revised 05 January 2014; accepted 08 January 2014) 